\title{
Short Communication: The composition of mangrove species in coastal area of Banggai District, Central Sulawesi, Indonesia
}

\author{
RAMLI UTINA ${ }^{1,2, \vartheta}$, ABUBAKAR SIDIK KATILI ${ }^{1,2, v v}$, NURAIN LAPOLO $^{3}$, TALHA DANGKUA ${ }^{4}$ \\ ${ }^{1}$ Department of Biology Faculty of Mathematics and Natural Sciences, Universitas Negeri Gorontalo. Jl. Jenderal Sudirman No. 6 Kota Gorontalo 96128 , \\ Indonesia. Tel.: +62-435-821125; Fax.: +62-435-821752."email: ramli.utina@ ung.ac.id; "v dikykatili@ gmail.com \\ ${ }^{2}$ Coastal Ecology Based on Local Wisdom Research Center, Universitas Negeri Gorontalo. Jl. Jenderal Sudirman No. 6 Kota Gorontalo 96128, Indonesia \\ ${ }^{3}$ Program of Population and Environmental Studies, Universitas Negeri Gorontalo. Jl. Jenderal Sudirman No. 6 Kota Gorontalo 96128, Indonesia \\ ${ }^{4}$ Department of Geography Faculty of Sciences and Technology, Universitas Muhammadiyah Gorontalo. Jl. Prof. Dr. Mansoer Pateda, Kabupaten \\ Gorontalo 96181, Indonesia
}

Manuscript received: 3 July 2018. Revision accepted: 26 February 2019.

\begin{abstract}
Utina R, Katili AS, Lapolo N, Dangkua T. 2019. Short Communication: The composition of mangrove species in coastal area of Banggai District, Central Sulawesi, Indonesia. Biodiversitas 20: 840-846. The mangrove ecosystem possesses unique ecological functions. This research is one part of the activities to prepare reports on mangrove condition in Banggai District, Central Sulawesi Province, Indonesia. The objectives of this study were to explore the composition of mangrove species and mangrove zoning in coastal area of Banggai. The data were collected by survey method spread within 16 spots, with a total area of 7,387 hectares. The data were analyzed with descriptive qualitative methods. The results showed that there were 32 families of mangrove plants in Banggai, classified into 53 species, consisting of 25 true mangrove species and 28 associated mangrove species. An endangered species of mangrove was found, i.e., Scyphiphora hydrophyllacea. This endangered species was found only in Tingki-tingki Village and Uwedikan Village (Balean and Potean Island) of Banggai. The pattern of mangrove zoning within the research site follows the pattern of mangrove zoning commonly found all over Indonesia. The Rhizophoraceae family (Bruguiera gymnorrhiza, Rhizophora mucronata, Rhizophora apiculata, Rhizophora stylosa, and Ceriops tagal) was found more often than the other families in the study site. It means that the Rhizophoraceae family had wide distribution area within sites.
\end{abstract}

Keywords: Diversity, mangrove vegetation, coastal area

\section{INTRODUCTION}

Mangroves are of great ecological importance and socio-economic significance as a hub for tropical marine organisms. The mangroves are also one of the world's richest storehouses of biological diversity. Furthermore, 90 $\%$ of the marine organisms spend part of their life in this ecosystem and $80 \%$ of the global fish catches are dependent on mangroves (Sandilyan and Kathiresan 2012). This ecosystem is featured with unique characteristics and various functions beneficial for human being and other organisms. A rational approach in mangrove utilization which involves the local community is essential for preservation of mangrove's ecological functions. Involvement of local community is considered as the preliminary step for sustainable mangrove preservation. This is in line with stated that, an approach that can be done to maintain the natural conditions of mangroves and make its ecosystem as a buffer zone by involving people around the mangrove area (Katili et al. 2017). Furthermore revealed that other ways to reduce mangrove degradation level that can be done is growing mangrove seedling and replanting the damaged area; introduction of various species of mangrove and its use through learning activities in schools around the mangrove area; and also hatcheries management while considering the suitability of environmental factors such as the type of substrate and salinity.

Banggai District, Central Sulawesi Province, Indonesia consists of essential seascape to the environment due to the presence of globally endangered species of flora and fauna, such as hawksbill turtle, giant clam, sea cucumbers, and others. The endangered status becomes worse because of damages to mangrove ecosystem and the coral reef. It is also contributed by illegal exploitation of marine resources using destructive methods, such as fishbombs, compressors, and poisonous chemicals. Aside from that, mangrove forest is highly prone to degradation as the aftermath of land conversion into fishponds, construction of infrastructure and for settlement, and illegal and excessive logging for house building material. In addition, the effort of raising people's awareness and environmental conservation is quite minimum alongside with insufficient availability of data and information of mangrove profile and its diversity. According to the report in 2010 from Regional Forestry Office of Central Sulawesi Province, most mangrove forests was seriously damaged: 5,652 ha out of 7,387 ha, in Banggai, 209 ha out of 350 ha in Eastern 
Luwuk District, and 605 ha out of 762 ha in Pagimana Subdistrict. The area was under protection and maintenance of local Forestry Office of Banggai District, but with the issuance of Law No. 23 in 2014 the authority is now under the Regional Forestry Office of Central Sulawesi Province, Indonesia.

Based on the critical situation described above, a study of the mangrove ecosystem in the area is considered crucial to conduct. This study is one part of the activity to reports on mangrove condition in Banggai. The objective of this study was to explore the composition of mangrove species and mangrove zoning.

\section{MATERIALS AND METHODS}

\section{Study area}

The research took place in 16 sites in 7,387 hectares of mangrove forest, Banggai District, Central Sulawesi Province, Indonesia as presented in Table 1 and Figure 1.

\section{Data collection}

The study was conducted using survey method, spread within 16 spots, with a total area of 7,387 hectares and the exploration method, based on the preliminary study and information of mangrove profile in Banggai. Table 2 displays the detailed methods of collecting data.

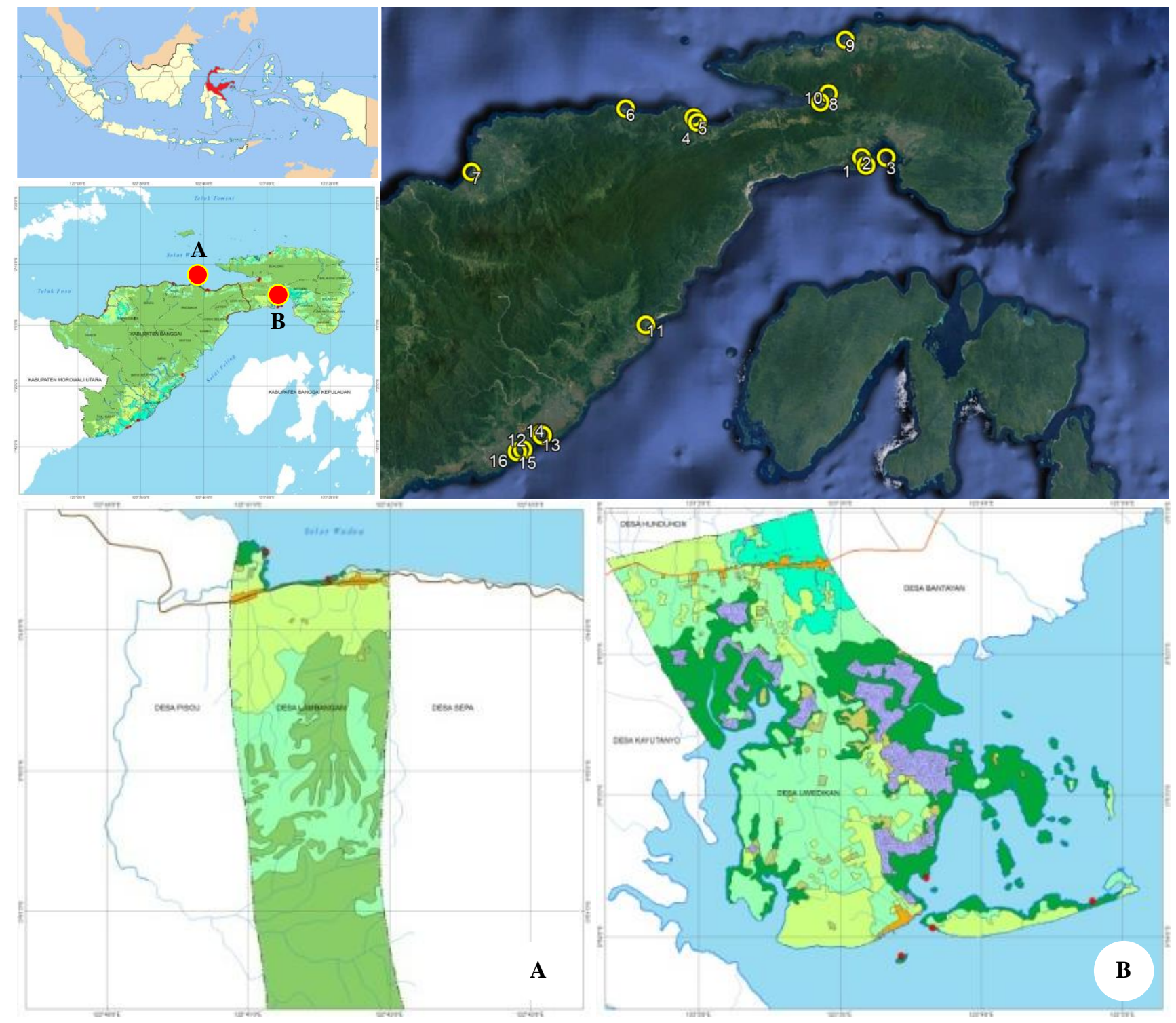

Figure 1. The study sites in Banggai District, Central Sulawesi Province, Indonesia; among the sites are: A. Lambangan Village, Pagimana Sub-district; and B. Uwedikan Village, Eastern Luwuk Sub-district; other sites can be seen in Table 1 
Table 1.Mangrove observation sites in Banggai District, Central Sulawesi, Indonesia

\begin{tabular}{lll}
\hline Site & & Coordinate \\
\hline 1 & Potean Island, Uwedikan Village, East Luwuk Sub-district & $0^{\circ} 54^{\prime} 16.3^{\prime \prime} \mathrm{S} 123^{\circ} 03^{\prime} 41.9^{\prime \prime} \mathrm{E}$ \\
2 & Balean Island, Uwedikan Village, East Luwuk Sub-district & $0^{\circ} 53^{\prime} 85.6^{\prime \prime} \mathrm{S} 123^{\circ} 3^{\prime} 62.1^{\prime \prime} \mathrm{E}$ \\
3 & Plain I, Uwedikan Village, East Luwuk Sub-district & $0^{\circ} 53^{\prime} 8.91^{\prime \prime} \mathrm{S} 123^{\circ} 6^{\prime} 30^{\prime \prime} \mathrm{E}$ \\
4 & Spot I, Lambangan Village, Pagimana Sub-district & $0^{\circ} 47^{\prime} 34.3^{\prime \prime} \mathrm{S} 122^{\circ} 39^{\prime} 42.9^{\prime \prime} \mathrm{E}$ \\
5 & Spot II, Lambangan Village, Pagimana Sub-district & $0^{\circ} 48^{\prime} 15.6^{\prime \prime} \mathrm{S} 122^{\circ} 40^{\prime} 15.9^{\prime \prime} \mathrm{E}$ \\
6 & Lobu Village, Lobu Sub-district & $0^{\circ} 46^{\prime} 19.9^{\prime \prime} \mathrm{S} 122^{\circ} 30^{\prime} 13.6^{\prime \prime} \mathrm{E}$ \\
7 & Petak village, Nuhon Sub-district & $0^{\circ} 55^{\prime} 14.4^{\prime \prime} \mathrm{S} 122^{\circ} 08^{\prime} 50.4^{\prime \prime} \mathrm{E}$ \\
8 & Mayayap village, Bualemo Sub-district & $0^{\circ} 44^{\prime} 8.54^{\prime \prime} \mathrm{S} 122^{\circ} 58^{\prime} 32.6^{\prime \prime} \mathrm{E}$ \\
9 & Toyiba village, Bualemo Sub-district & $0^{\circ} 36^{\prime} 27.2^{\prime \prime} \mathrm{S} 123^{\circ} 0^{\prime} 57.3^{\prime \prime} \mathrm{E}$ \\
10 & Conservation site of the National Army, Siuna Village, Pagimana Sub-district & $0^{\circ} 45^{\prime} 22.1^{\prime \prime} \mathrm{S} 122^{\circ} 57^{\prime} 24.7^{\prime \prime} \mathrm{E}$ \\
11 & Tingki-tingki village, Southern Batui Sub-district & $1^{\circ} 16^{\prime} 25.6^{\prime \prime} \mathrm{S} 122^{\circ} 33^{\prime} 13.6^{\prime \prime} \mathrm{E}$ \\
12 & Tohiti Sari I Village, Toili Sub-district & $1^{\circ} 31^{\prime} 18.5^{\prime \prime} \mathrm{S} 122^{\circ} 19^{\prime} 0.3^{\prime \prime} \mathrm{E}$ \\
13 & Tohiti Sari II Village, Toili Sub-district & $1^{\circ} 31^{\prime} 17.9^{\prime \prime} \mathrm{S} 122^{\circ} 18^{\prime} 59.8^{\prime \prime} \mathrm{E}$ \\
14 & Pandan Wangi Village, Western Toili Sub-district & $1^{\circ} 31^{\prime} 28.3^{\prime \prime} \mathrm{S} 122^{\circ} 19^{\prime} 10.5^{\prime \prime} \mathrm{E}$ \\
15 & Kamiwangi Village, Western Toili Sub-district & $1^{\circ} 33^{\prime} 41.8^{\prime \prime} \mathrm{S} 122^{\circ} 15^{\prime} 47.1^{\prime \prime} \mathrm{E}$ \\
16 & Palm Oil Plantation Area, Toili Sub-district & $1^{\circ} 33^{\prime} 25.3^{\prime \prime} \mathrm{S} 122^{\circ} 16^{\prime} 32.2^{\prime \prime} \mathrm{E}$ \\
\hline
\end{tabular}

Table 2. The techniques of collecting data and information of mangrove survey in Banggai District, Central Sulawesi, Indonesia

\begin{tabular}{ll}
\hline Data and information needed & $\begin{array}{l}\text { The methods of collecting } \\
\text { data }\end{array}$ \\
\hline $\begin{array}{l}\text { Identification of mangrove } \\
\text { species }\end{array}$ & $\begin{array}{l}\text { By exploration and visual } \\
\text { observation }\end{array}$ \\
$\begin{array}{l}\text { The biophysical condition, } \\
\text { potential resources of mangrove, } \\
\text { perception level, community }\end{array}$ & $\begin{array}{l}\text { By site observation and } \\
\text { interview/discussion } \\
\text { participation, and management } \\
\text { policy of mangrove ecosystem in } \\
\text { the research site villages and } \\
\text { other location in Banggai District }\end{array}$ \\
\hline
\end{tabular}

\section{RESULTS AND DISCUSSION}

\section{Composition and distribution of mangrove species}

Almost all Banggai is featured with mangrove ecosystem. The results showed that there were 32 families, consisting of 53 species, 25 of which are true mangrove species and 28 associated mangrove species (Table 3). Among the true mangrove species growing in Banggai are Avicennia, Sonneratia, Rhizophora, Bruguiera, Xylocarpus, and Lumnitzera. The interview results indicated that the community in Banggai has not developed an intimate connection with the mangrove ecosystem, as observed from the community's lack of knowledge of mangrove and its local term within the area. In general, the Saluan community within coastal area addresses mangrove species by local terms. One of the most well-known mangrove species, Rhizophora apiculata, is known by the locals as Lolaro. A species of endangered mangrove, i.e., Scyphiphora hydrophyllacea was found, but its distribution was limited to Tingki-tingki, Southern Batui and in Uwedikan (Balean and Potean island) Eastern Luwuk Subdistrict, Banggai. The mangrove area in Uwedikan is also rich with various species of animals, i.e., fiddler crabs, Scylla serrata, reptiles like snakes and lizards, and some protected species. There are endemic birds during specific seasons in the area, although the species are unidentified.
Tables 3 and 4 show that Rhizophoraceae has the highest number of species, namely Bruguiera gymnorrhiza, Rhizophora mucronata, R. apiculata, Rhizophora stylosa, and Ceriops tagal. Among those with limited distribution are Meliaceae family (species Xylocarpus granatum), Verbenaceae family (genus: Avicennia), and Lumnitzera littorea. Achantus illicifolius, a mangrove bush species is also found growing in the brackish marsh area and dry plains only reachable by high tide. The lack of freshwater in the form of brackish marsh contributes to the rarity of the species in the area. Achrosticum sp., a species growing in similar habitat with A. illicifolius is also rare. C. tagal is distributed widely along the coastline near the land. The dry plains with sand substrate and soft sediments are mostly found in the sedimented area. The height of mangrove stand is generally short, less than 4 meters, but it can be higher in conservation sites, such as Uwedikan and Lambangan, and some inland previously utilized as fishponds in Tingki-tingki, Southern Batui District. The mangrove trees are prone to logging (for firewood and fence) and, in consequence, the community becomes open with branched trees. To make matter worse, the mangrove is usually converted into fishponds.

Rhizophora apiculata is widely distributed in the transition of back and middle zones. The species is rarely found in the forest; rather, it is often found growing near $C$. tagal, with stem height of 2 meters higher than that of $C$. tagal. It has lateral branches because the main tree trunks are cut down. This species, compared to $R$. mucronata, is less widely distributed in Uwedikan and Lambangan.

Rhizophora mucronata is more evenly and widely distributed than $R$. apiculata, ranging from muddy area at the back zone to the coastline near the islands. The trunk can grow bigger at the middle zone to near the sea; some parts may reach dieback phase. Bruguiera gymnorrhiza can grow in the middle zone. The tree bark of this species is often exploited for net coloring, building material, and firewood. The species is mainly found in Uwedikan, particularly in Potean and Balean islands. B. gymnorrhiza is one of the widely distributed species within the research site, ranging from land area to the coastline. This species 
grows alongside $R$. mucronata. The trees are quite big, and some are found in dieback phase. The species' saplings are commonly found in Uwedikan, Lambangan, and in other locations, i.e., river estuary in Kamiwangi and Tohiti Sari. On the other hand, Sonneratia alba has limited distribution, and is found only along the coastline with sand substrate and affected by tidal wave such as in Lambangan. Due to the muddy characteristic of the coast, the species is distributed widely within Lambangan. When the tree grows large, this species is regularly chosen for logging due to its high wood quality. Avicennia marina has limited distribution, as it is found only in sandy land near the river estuary (in Kamiwangi and Tohiti Sari). Rarely forming high structure, its trunk grows larger and it is found abundantly alongside C. tagal and S. alba.

Table 3. The species of true mangrove in Banggai District, Central Sulawesi Province, Indonesia

\begin{tabular}{|c|c|c|}
\hline Family & Scientific name & Local name \\
\hline \multirow[t]{6}{*}{ Acanthaceae } & Acanthus ebracteatus & Jeruju (Bajo) \\
\hline & & Kantung-kantung (Saluan) \\
\hline & Acanthus ilicifolius & Jeruju (Bajo) \\
\hline & & Kantung-kantung (Saluan) \\
\hline & Acanthus volubilis & Jeruju (Bajo) \\
\hline & & Kantung-kantung (Saluan) \\
\hline \multirow[t]{2}{*}{ Arecaceae } & Nypa fruticans & Nipah (Saluan) \\
\hline & & Pagoh (Bajo) \\
\hline \multirow[t]{3}{*}{ Avicenniaceae } & Avicennia lanata & Api-api (Saluan, Bajo) \\
\hline & Avicennia marina & Api-api (Saluan, Bajo) \\
\hline & Avicennia officinalis & Api-api (Saluan, Bajo) \\
\hline \multirow[t]{4}{*}{ Combretaceae } & Lumnitzera littorea & Manjarite (Bajo) \\
\hline & & Kau bunga (Saluan) \\
\hline & Lumnitzera racemosa & Manjarite (Bajo) \\
\hline & & Kau bunga (Saluan) \\
\hline \multirow[t]{2}{*}{ Euphorbiaceae } & Excoecaria agallocha & Buta-buta (Saluan) \\
\hline & & Bubuta (Bajo) \\
\hline \multirow[t]{3}{*}{ Lythraceae } & Pemphis acidula & Pisang-pisang (Bajo) \\
\hline & & Santigi (Kendari) \\
\hline & & Kayu udung (Saluan) \\
\hline \multirow[t]{2}{*}{ Meliaceae } & Xylocarpus granatum & Kalentabu (Saluan) \\
\hline & & Tatambu (Bajo) \\
\hline \multirow[t]{2}{*}{ Pteridaceae } & Acrostichum aureum & Piai, Munto (Bajo) \\
\hline & & $\begin{array}{l}\text { Hompiyou, Tongke } \\
\text { (Saluan) }\end{array}$ \\
\hline \multirow[t]{14}{*}{ Rhizophoraceae } & Bruguiera cylindrica & Tongke (Saluan) \\
\hline & & Munto (Bajo) \\
\hline & Bruguiera & Tongke (Saluan) \\
\hline & gymnorrhiza & Munto (Bajo) \\
\hline & Bruguiera sexangula & - \\
\hline & Ceriops decandra & Kokuni (Saluan) \\
\hline & & Tingar (Bajo) \\
\hline & Ceriops tagal & Kokuni (Saluan) \\
\hline & & Tingar (Bajo) \\
\hline & Rhizophora apiculata & Lolaro (Saluan) \\
\hline & Rhizophora mucronata & Akat (Saluan) \\
\hline & & Tongke (Bajo) \\
\hline & Rhizophora stylosa & Loraro (Saluan) \\
\hline & & Tongke (Bajo) \\
\hline & Scyphiphora hydrophyllacea & Papa (Bajo) \\
\hline \multirow[t]{4}{*}{ Sonneratiaceae } & Sonneratia alba & Popat (Saluan) \\
\hline & & Paranga (Bajo) \\
\hline & Sonneratia ovata & Popat (Saluan) \\
\hline & & Paranga (Bajo) \\
\hline Sterculiaceae & Heritiera littoralis & Dungun (Saluan) \\
\hline
\end{tabular}

Table 4. The species of associated mangrove in Banggai District, Central Sulawesi Province, Indonesia

\begin{tabular}{|c|c|c|}
\hline Family & Scientific name & Local name \\
\hline Apocynaceae & Cerbera manghas & - \\
\hline Aquifoliaceae & Ilex cassine & - \\
\hline \multirow[t]{2}{*}{ Asclepiadaceae } & Calotropis gigantea & - \\
\hline & Finlaysonia maritima & - \\
\hline Asteraceae & Wedelia biflora & $\begin{array}{l}\text { Komba-komba (Bajo, } \\
\text { Saluan) }\end{array}$ \\
\hline Bignoniaceae & Dolichandrone spathacea & - \\
\hline Combretaceae & Terminal catappa & $\begin{array}{l}\text { Talisei (Bajo) } \\
\text { Toluse (Saluan) }\end{array}$ \\
\hline Convolvulaceae & Ipomoea pes-caprae & $\begin{array}{l}\text { Sumboh (Bajo) } \\
\text { Kela-kela (Saluan) }\end{array}$ \\
\hline Euphorbiaceae & Ricinus communis & Jarak (Saluan, Bajo) \\
\hline \multirow[t]{3}{*}{ Fabaceae } & Dalberga candenatensis & - \\
\hline & Derris trifoliata & - \\
\hline & Pongamia pinnata & Pelaing (Saluan) \\
\hline \multirow[t]{2}{*}{ Goodeniaceae } & Scaevola taccada & Kalaso (Bajo) \\
\hline & & Lintoboi (Saluan) \\
\hline Gramineae & Spinifex littoreus & Rumput jalenje (Bajo) \\
\hline \multirow{2}{*}{ Guttiferae } & Calophyllum & Dangkalang (Bajo) \\
\hline & inophyllum & Dongkalan (Saluan) \\
\hline \multirow[t]{2}{*}{ Malvaceae } & Hibiscus tiliaceus & Baru (Bajo) \\
\hline & & Bahu (Saluan) \\
\hline Melastomataceae & Melastoma candidum & - \\
\hline Meliaceae & Aglaia cucullata & - \\
\hline Molluginaceae & Sesuvium portulacastrum & Simput Bose (Saluan) \\
\hline \multirow[t]{3}{*}{ Pandanaceae } & Pandanus odoratissima & $\begin{array}{l}\text { Anyamon (Saluan) } \\
\text { Pandan Bador (Bajo) }\end{array}$ \\
\hline & Pandanus tectorius & Tole (Saluan) \\
\hline & & Pandan Bador (Bajo) \\
\hline Rubiaceae & Morinda citrifolia & - \\
\hline \multirow[t]{3}{*}{ Verbenaceae } & Clerodendrum inerme & - \\
\hline & Stachytarpheta jamaicensis & Ekor tikus (Saluan) \\
\hline & Premna serratifolia & - \\
\hline
\end{tabular}

Xylocarpus granatum has wide distribution. It is found growing in dry plains. It is also found growing along the tidal river flow and near dry fishponds, alongside other vegetation in a dry habitat, e.g., $L$. littorea and $L$. racemosa. The species is mainly found in Uwedikan, particularly at river estuary in Kamiwangi. Pemphis acidula is only found in dry plains with sand substrate. This species is capable of growing on sand dunes that are not reachable by the tidal wave, such as on the coastline in Potean and Balean islands, Uwedikan. Meanwhile, Nypa fruticans is not found growing anywhere other than on river flows in Kamiwangi and Tohiti Sari. Scyphyphora hydrophyllacea has restricted distribution, as it is found only in Uwedikan and on the land previously utilized as fishponds in Tingki-tingki, Southern Batui.

\section{Zoning pattern of mangrove in Banggai}

Overall, the pattern of mangrove zoning at the site follows the pattern of mangrove zoning commonly found in Indonesia (Figure 2). The zoning pattern of mangrove is considered important among researchers since it is interpreted as successional stages (progressive change in 
species composition during vegetation development). Mangrove zonation is induced by delta morphodynamics, such as the abandonment of a distributary triggering subsidence or the shifting of the active center of deposition (Bullock et al. 2017). The surface's physiography is considered to play a significant role in affecting the zoning pattern since the slope of the land surface determines the duration and width of tidal inundation. Surface's physiography also contributes to water's salinity and flow, soil aeration, tidal range, and microclimate; these are crucial elements affecting the zoning formation. On top of that, damages to the mangrove ecosystem in study site, i.e., logging by the community and conversion to fishponds, give negative impact on mangrove zoning and mangrove forest growth. The damage to the mangrove ecosystem can also cause changes in the coastline. This is in line with stated by Tinh and Hens (2017), that changes in mangrove coastline are considered as a parameter to monitor changes in coastal environment as indicators of global warming, climate change, storm effects, sea level changes, pollution, and sedimentation rates.
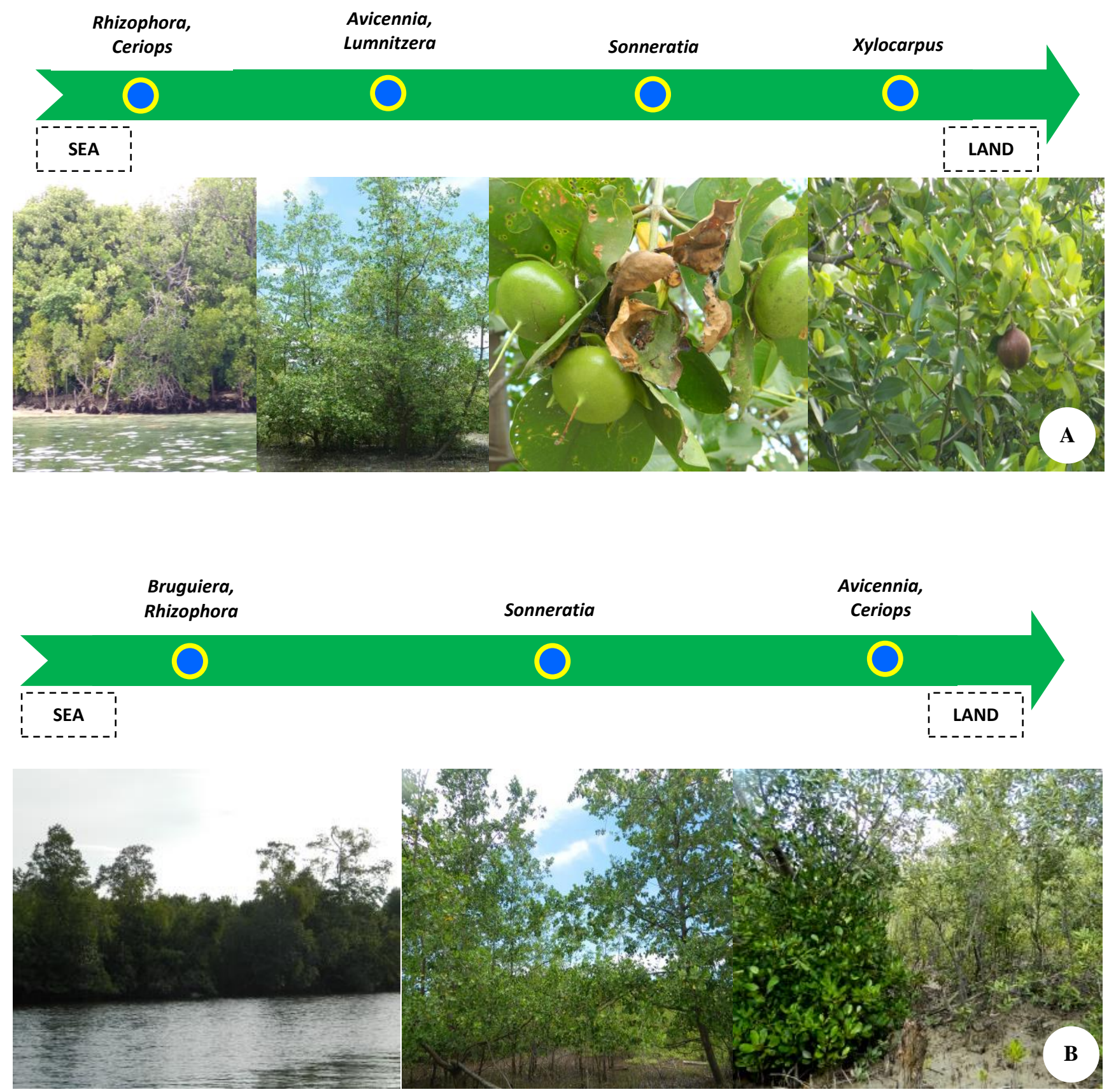

Figure 2. Zoning pattern in coastal area of Banggai District, Central Sulawesi, Indonesia. A. Uwedikan, B. Lambangan 


\section{Discussion}

In general, the mangrove forest in Uwedikan is categorized as overwash mangrove which means typical forest in separated islands. Certain species dominate in the study location because of their adaptability to environmental factors, mainly substrate types in the research site, which is mixture between sand and mud. Each species is featured with different tolerance range to various environmental conditions mainly substrate types, in which the research site is mainly composed of sand and mud substrate. Mangrove substrate is formed from the presence of sediment trapped in the mangrove ecosystem. This also related to physicochemical characters of sediment. The overwash mangrove type show differences in physicochemical characteristics of sedimentary soils and this contributes to the diversity of species available (Retnowati et al. 2017). In order to grow optimally, each species requires different growth condition. It can be assumed that the Rhizophoraceae family tends to adapt well to the environmental condition in the mangrove community in the research site. As research conducted by Canizares et al. (2016) revealed that Rhizophoraceae family is a large-leafed mangrove and one of the most important and widespread mangrove species in the Pacific. It is found in intertidal areas of the tropical Pacific region from Southeast Asia to southern Japan in Micronesia and Polynesia (Samoa), and southward to subtropical Australia. While the location of this study is part of the Southeast Asia region and it can prove the assumption above.

The species within Rhizophoraceae are among the most significant and most widely distributed mangrove species. The species dominance could reach $90 \%$ of the total vegetation within site, with optimal grow usually occurs in a land with deep inundation and soil with abundant humus; on top of that, the species' inflorescence occurs throughout the year (Noor et al. 2012). According to Twilley and Day (2012) there are three genera in the Rhizophoraceae family found only in the old world tropics.

Another dominant genus in old world tropics is Sonneratia (Sonneratiaceae), which has five species. Most of the minor components that are relatively rare of mangroves are located in the old world tropics (nearly 19 species), with only one, Pelliciera, located in the new world tropics. A study by Soeroyo and Achmad (2002) indicates that Rhizoporaceae family dominates the front zone of mangrove forest all over Sulawesi. The result is in line with the result of this research because the family contributes relatively high to the mangrove community within the research site in Banggai.

Wirakusumah (2003) mentions that species with even distribution are significant within a community due to the ability to adapt well to the different environment. The other than that the anatomical and morphological characteristics of plants are commonly correlated with a particular environmental condition where they are growing (Arrivabene et al. 2014). Rhizophoraceae has a morphological form that can adapt well to sandy-muddy substrates because it has a supporting root shape. Therefore, it is predicted that the species in Rhizophoraceae will show more even and wider distribution in the near future. On top of that, taxonomically, species in the Rhizophoraceae family tend to possess ecophysiological similarity in adapting to the environment. The family is featured with a specific life cycle, starting from seed in the parent plant which germinates and begins to grow into a seedling while it is still attached to the tree. During the process, the seedling elongates and its weight distribution changes, making the seedling heavier in the outer part and finally separates. The seedling then drops from parent plant into the shallow coastal waters, consequently, its roots penetrate the soil and it starts to grow gradually into a fully-grown tree (Bengen 2002). The unique life cycle is believed to be one of the contributing factors to the dominance of Rhizophoraceae family.

Moreover, Bengen (2002) states that mangrove forest is mainly dominated by four genera, one of which is a genus of Rhizophoraceae that is featured with unique adaptability in the muddy substrate with the acidic and anoxic characteristic. The Rhizoporaceae family is known to adapt well in low oxygen level, high salt level, unstable land, and inland exposed to tidal waves. Aside from that, the seedling production in the mangrove forest is affected by the number of productive trees with large diameters (parent trees).

Other than Rhizophoraceae family, the study discovered other families and species, e.g., Meliaceae (Xylocarpus granatum), Verbenaceae (Avicennia), and Lumnitzera littorea species with limited distribution. This is supposedly caused by a physical characteristic of research sites as a logged-over area. Xylocarpus granatum (Koen) is abundant in the logged-over area and another damaged area (Noor et al. 2012). Similar to this study reported that Xylocarpus granatum was the co-dominant species recorded in the mangrove forest or can be said its a second species that has limited distribution in mangrove forests. Rhizophora and Xylocarpus may associate in the mangrove community as observed from its zoning (Hoque at al. 2015).

To conclude, there are 32 families of mangrove in the site of research, consisting of 53 species, classified into 25 true mangroves and 28 associated mangroves. Rhizophoraceae has more species than other families. There is an endangered mangrove species, i.e., Scyphiphora hydrophyllacea.

\section{ACKNOWLEDGEMENTS}

The authors would like to thanks to several parties whose supports and contribution to this study, i.e., JAPESDA (Institute for Advocacy Network of Natural Resources Management) Gorontalo; the Government of Banggai District, Uwedikan Village, and Lambangan Village; and Coastal Ecology Based on Local Wisdom Research Center, Department of Biology, Faculty of Mathematics and Natural Sciences, Universitas Negeri Gorontalo, Indonesia. The authors also gratefully acknowledge the funding from USAID through the SHERA program-Centre for Development of Sustainable Region (CDSR). 


\section{REFERENCES}

Arrivabene HP, Souza L, Oliveira Có WL, Rodella RA, Wunderlin DA, Milanez CR. 2014. Functional traits of selected mangrove species in Brazil as biological indicators of different environmental conditions. Sci Total Environ 476-477: 496-504

Bengen DG. 2002. Introduction and Management of Mangrove Ecosystems. Center for Coastal and Marine Resources Studies, Bogor Agricultural University, Bogor. [Indonesian]

Bullock E L, Fagherazzi S, Nardin W, Vo-Luong P, Nguyen P, Woodcock CE. 2017. Temporal patterns in species zonation in a mangrove forest in the Mekong Delta, Vietnam, using a time series of Landsat imagery. Cont Shelf Res. DOI: 10.1016/j.csr.2017.07.007.

Canizares LP, Seronay R A. 2016. Diversity and species composition of mangroves in Barangay Imelda, Dinagat Island, Philippines. AACL Bioflux 9 (3): 518-526.

Hoque MM, Kamal AHM, Idris MH, Ahmed OH, Hoque RATM, Billah MdM. 2015. Litterfall production in a tropical mangrove of Sarawak, Malaysia. Zool Ecol 25 (2): 157-165,

Katili AS, Ibrahim M, Zakaria Z. 2017. Degradation level of mangrove forest and its reduction strategy in Tabongo Village, Boalemo District, Gorontalo Province, Indonesia. Asian J For 1 (1): 18-22
Noor YR, Khazali M, Suryadiputra INN. 2012. The third printing guide for Mangrove Indonesia in 2012. Wetlands International Indonesia Programme. Bogor.

Retnowati Y, Sembiring L, Moeljopawiro S, Djohan TS, Soetarto ES. 2017. Diversity of antibiotic-producing actinomycetes in mangrove forest of Torosiaje, Gorontalo, Indonesia. Biodiversitas 18 (3): 14531461

Sandilyan S, Kathiresan K. 2012. Mangrove conservation: a global perspective. Biodivers Conserv 21: 3523-3542.

Soeroyo AK. 2002. Conditions and Types of Mangroves in the North Sulawesi Region. Research Center for Oceanographic, LIPI, Jakarta.

Thinh NgA, Hens L. 2017. A Digital Shoreline Analysis System (DSAS) applied on mangrove shoreline changes along the Giao Thuy Coastal area (Nam Dinh, Vietnam) during 2005-2014. Vietnam J Earth Sci 39 (1): 87-96.

Twilley RR, Day JW. 2012. Mangrove Wetlands. In: Day JWJr, Crump BC, Kemp WK, Yanez-Arancibia A. (eds.) Estuarine Ecology, 2nd ed. John Wiley \& Sons, Inc., New York.

Wirakusumah S. 2003. Fundamental Ecology for Populations and Communities. UI-Press. Jakarta [Indonesian] 